\title{
Przemiany w kulturze muzycznej Sumatry Zachodniej na przykładzie wykorzystania fletu saluang darek
}

\section{Changes in the musical culture of West Sumatra on the example of the use of flute saluangdarek}

\author{
Maria Szymańska-Ilnata \\ MUZEUM AZJI I PACYFIKU W WARSZAWIE, INSTYTUT SZTUKI PAN \\ mariaszymanskailnata@muzeumazji.pl
}

\begin{abstract}
Abstrakt
Saluang darek jest uznawany za jeden z najstarszych i autochtonicznych instrumentów wykorzystywanych w muzyce przez ludzi Minangkabau. Jego nazwa pochodzi od regionu Darek zwanego też Luhak Nan Tigo i stanowiącego kolebkę kultury Minangkabau. Saluang darek jest instrumentem o prostej konstrukcji bambusowej rury otwartej na obu końcach, posiadającej cztery otwory palcowe. Taka budowa wymaga jednak stosowania specyficznej i trudnej techniki gry. Jego dźwięk jest bardzo charakterystyczny i stanowi współcześnie jeden z elementów używanych do budowania poczucia tożsamości etnicznej wśród ludzi Mianankgabau. Tradycyjnie stosowano saluang jako instrument akompaniujący do rzewnych, nostalgicznych pieśni oraz jako medium do kontaktu z duchami. W latach 70. wraz ze wzrostem popularności muzyki rozrywkowej narodził się gatunek saluang dangdut, w którym radosnym melodiom granym na flecie towarzyszą bębny i śpiew. Gatunek ten ewoluował do bardzo popularnego dziś Pop-Minang. W artykule przedstawione zostaną współczesne pola eksploatacji fletu saluang darek oraz wpływ obcych kultur i massmediów na wykonywaną na nim muzykę.
\end{abstract}

\begin{abstract}
Saluangdarek is recognized as one of the oldest and indigenous instruments used in music by the Minangkabau people. Its name comes from the region Darek also called Luhak Nan Tigo and forming the heartland of Minangkabau culture. Saluangdarek is an instrument of
\end{abstract}


simple construction - a bamboo tube open at both ends, having four finger holes. This construction, however, requires the use of specific and difficult playing technique. The sound of this flute is very distinctive and is today one of the elements used to build a sense of ethnic identity among the Minankgabau people. Saluang traditionally was used as an instrument accompanying the doleful, nostalgic songs as well as a medium to contact the spirits. In the 700 the new music genre called saluang dangdut was developed, where joyful melodies are played on the flute, accompanied by drums and singing. This genre has evolved into a very popular nowadays Pop Minang. The article presents the contemporary use of saluangdarekflute and the influence of foreign cultures and the mass media on the music in Minangkabau region.

\section{Obszar badań ${ }^{1}$}

Sumatra Zachodnia to prowincja Indonezji obejmująca zachodnie wybrzeże Sumatry oraz archipelag wysp Mentawai. Sumatrzańską część prowincji zamieszkują przede wszystkim członkowie grupy etnicznej Minangkabau, których kultura muzyczna jest przedmiotem niniejszego artykułu. Tradycje muzyczne mieszkańców wysp Mentawai, choć nie mniej ciekawe, nie będą tutaj omawiane ze względu na swoją odmienność. Uwarunkowania geograficzne sprawiły, że przez setki lat obie kultury rozwijały się niezależnie i prawdopodobnie miały ze sobą jedynie sporadyczny kontakt.Z tego powodu ich dzisiejsza kondycja jest zupełnie odmienna, co całkowicie wyklucza jakiekolwiek ich porównywanie.

Region zamieszkiwany przez ludzi Minangkabau - Alam Minangkabau (Świat Minangkabau) dzielony jest ze względów historycznych na dwie części - zasiedloną wcześniej Luahak Nan Tiga zwaną też Darek, składającą się z Luah Tanah Datar, Luhak Limapuluh Kota i Luhak Agam oraz obszary migracyjne zwane rantau², które historycznie obejmowały tereny należące obecnie do pozostałych regencji Zachodniej Sumatry. Współcześnie cały ten obszar uznawany jest za ojczyznę ludzi Minangkabau, a terminem rantau określane są dalsze

\footnotetext{
1 Tekst powstał w trakcie realizacji projektu „Kultura muzyczna Sumatry w świetle źródeł historycznych i terenowych badań współczesnych" sfinansowanego ze środków Narodowego Centrum Nauki przyznanych na podstawie decyzji numer DEC-2013/09/N/HS2/02145

${ }^{2}$ Rantau to zwyczaj, zgodnie z którym młody mężczyzna powinien opuścić rodzinną wioskę i wyruszyć $\mathrm{w}$ podróż $\mathrm{w}$ poszukiwaniu życiowego doświadczenia i pieniędzy oraz udowodnienia swojej dojrzałości. Po powrocie z trwającej zwykle ok. 1 roku wędrówki uznawany był za gotowego do zawarcia małżeństwa i założenia własnej rodziny. W praktyce jednak wielu mężczyzn wybierało życie na emigracji, żeniło się z poznanymi podczas podróży kobietami lub wracało na krótko do rodzinnej wioski, aby się tam ożenić i zabrać swoją żonę ze sobą, do nowego miejsca zamieszkania. Tradycja rantau uznawana jest za główną przyczynę powstawania licznych diaspor ludności Minangkabau nie tylko w Indonezji, ale na całym świecie.
} 
obszary migracyjne - inne indonezyjskie prowincje oraz państwa (Fraser 2015, 12). Istnienie diaspor Minangkabau w różnych zakątkach globu ma istotne znaczenie dla współczesnych przemian w kulturze muzycznej Sumatry. Silnie rozwijający się przemysł muzyczny na Sumatrze Zachodniej stara się sprostać oczekiwaniom nie tylko lokalnych mieszkańców, ale także zaspokoić gusta emigrantów oraz ich potomków. Powstają zatem nowe gatunki muzyczne, łączone są różne style, a efekty tych działań mają świadczyć zarówno o przywiązaniu do tradycji jak iotwarciu na nowoczesny, zmieniający się świat.

\section{Saluang darek}

Nazwa instrumentu, któremu poświęcony jest niniejszy artykuł wywodzi się od słowa aluang, które w dialekcie Minangkabau oznacza dźwięk. Przedrostek sa to początek słowa satu (jeden). Sa+aluang oznacza zatem jeden dźwięk (Erizal 1990, 28)3. Nazwa ta wiąże się z solowym występowaniem tego instrumentu, który w kulturze Minangkabau traktowany jest także jako medium służące do przekazywania treści, które trudno wyrazić za pomocą słów. Drugi człon nazwy instrumentu pochodzi od nazwy obszaru, na którym jest on szczególnie popularny, to jest od obszaru zwanego Darek, uznawanego za kolebkę kultury Minangkabau. Znany jest jednak także poza tym obszarem, między innymi na terenach określanych mianem historycznego rantau czyli w Kabupatan Pasaman, Kabupaten Solok, Kabupaten Sawahlunto Sijunjung, Kabupaten Padang Pariaman, Kabupaten Pesisir Selatan (Syeilendra 2000, 53). Wszystkie występujące na tym terenie flety określane są terminem saluang natomiast ich typy dookreślane są za pomocą drugiego członu nazwy, który często pochodzi od nazwy regionu, dla którego dany typ instrumentu jest charakterystyczny. Przykładem jest chociażby saluang pauh, z regionu Padang Pauh.

Saluang darek to piszczałka prosta o zadęciu krawędziowym, wytwarzana z odpowiednio dobranej i przygotowanej łodygi bambusa. Dawniej miała ona trzy otwory palcowe, ale współcześnie częściej wykonywane są cztery (Syeilendra 2000, 53). Zazwyczaj wykorzystywane są bambusy o dość dużej średnicy, wynoszącej mniej więcej 3-3,5 cm. Po wybraniu odpowiedniej łodygi jest ona ścinana i suszona na słońcu przez kilka dni lub tygodni. W trakcie tego procesu staje się coraz bardziej pożółkła i na podstawie jej barwy osoba wykonująca flet ocenia kiedy przystąpić można do kolejnych prac. Wybiera ona także odcinek bambusa, z którego wykonywać będzie flet $\mathrm{i}$, jeśli jest to konieczne, odcina niepotrzebną jego część ustalając tym samym koniec instrumentu. W celu określenia miejsc otworów palcowych obwód bambusa mierzony jest sznurkiem. Na podstawie otrzymanego w ten sposób odcinka odmierzane są odległości pomiędzy otworami. Same otwory mają zwykle średnicę około $1 \mathrm{~cm}$ i wypalane są przy użyciu metalowego, rozgrzanego w ogniu pręta.

3 Wszystkie tłumaczenia z jęz. angielskiego i indonezyjskiego -M. Szymańska-Ilnata 
Położenie pierwszego $\mathrm{z}$ nich odmierzana jest od końca instrumentu, w odległości równej obwodowi fletu pomniejszonemu o ok. $1 \mathrm{~cm}$. Odległości pomiędzy poszczególnymi otworami wynosić powinny tyle, co pół długości obwodu fletu. Drugi koniec instrumentu odmierzony powinien zostać od ostatniego otworu palcowego i znaleźć się w odległości trzy- lub czterokrotności obwodu fletu. Końcówka bambusa, której krawędź służyć będzie do zadęcia, powinna zostać delikatnie spiłowana, w celu uzyskania cieńszych ścianek (Erizal 1990, 32-33).

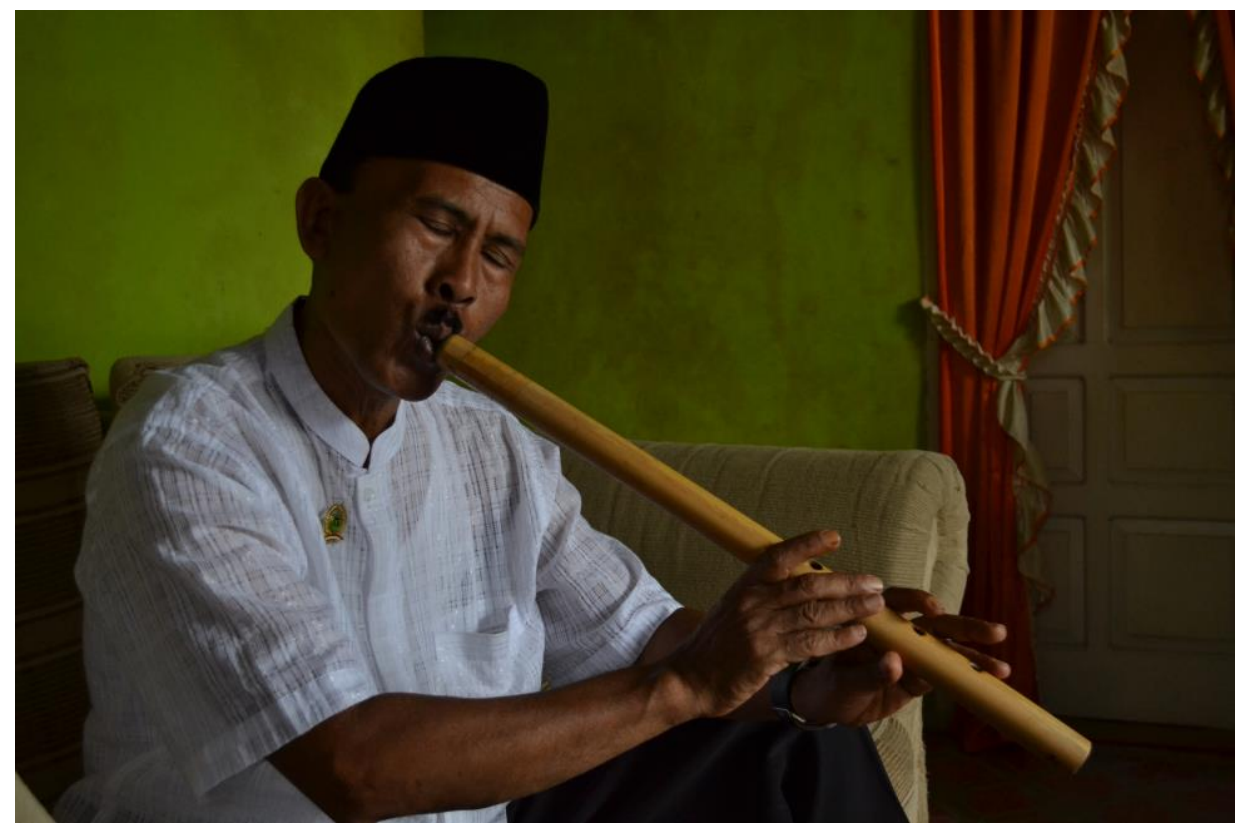

Fot. 1 Mawardi B.A. grający na saluang darek; fot. M. Szymańska-Ilnata, $2013 \mathrm{r}$.

Opisane powyżej parametry fletu dotyczą tak zwanego saluangklasik, czyli fletu używanego do wykonywania tradycyjnego repertuaru muzycznego. Współcześnie stosowane są jednak również flety o mniejszej średnicy, a zatem wyższym brzmieniu, na których wykonywany jest akompaniament do bardziej nowoczesnych utworów. Na obu typach fletów grają ci sami muzycy, którzy zwykle mają przy sobie kilka instrumentów o różnym stroju. Pozwala im to dobierać podczas występu instrument najlepiej pasujący do głosu śpiewaka, któremu towarzyszą (Bolon 2015; Katik Parau 2015).

Technika gry na saluang darek jest chyba najtrudniejsza spośród stosowanych do gry na aerofonach na obszarze Minangkabau. Aby wydobyć dźwięk muzyk przechyla głowę,tworzy z ust niewielki otwór skierowany w bok, język przyciska do linii zębów, a policzkiem zamyka część otworu instrumentu. Podczas gry ułożenie ust nie może być zmieniane (Syeilendra 2000, 53), natomiast instrument jest na przemian dociskany i lekko oddalany od ust muzyka, co daje efekt dość silnego vibrato. 
Maria Szymańska-Ilnata: Przemiany w kulturze muzycznej Sumatry

Zachodniej na przykładzie wykorzystania fletu saluang darek

\section{Zastosowanie saluang darek}

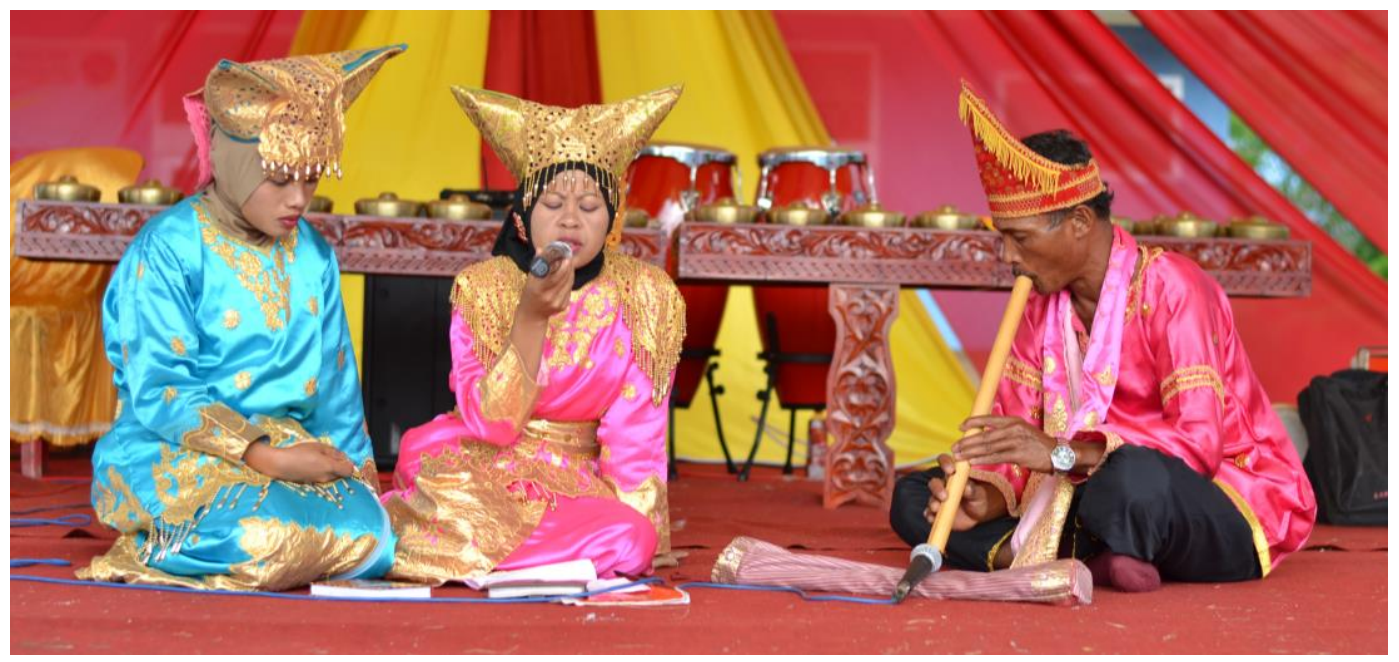

Fot. 2 Muzyk grający na saluang darek i dwie śpiewaczki; fot. M. Szymańska-Ilnata, 2013 r.

Saluang darek jest zdecydowanie instrumentem świeckim i nie jest stosowany podczas uroczystości religijnych. Można za jego pomocą wyrażać i przekazywać emocje. Jak pisze Syeilendra „zazwyczaj saluang darek pełni funkcję rozrywki osobistej, pozwala zapomnieć o tęsknocie, niepokoju o kogoś bliskiego" (Syeilendra 2000, 54). Występować może jako instrument solowy, jednak częściej towarzyszy śpiewom zwanym dendang. Grywają na nim przedstawiciele różnych pokoleń, gdyż służyć może także do żartów podczas spotkań towarzyskich, które odbywają się najczęściej na osiedlu, w domu lub przed nim. Przy dźwiękach tego fletu mają miejsce żartobliwe pogawędki, ale także recytacje tradycyjnej poezji oraz śpiew. Nie zawsze są to już ułożone i znane piosenki. Teksty powstawać mogą spontanicznie i odnosić się do bieżących wydarzeń. Warto podkreślić, że jeszcze do połowy XX w. spotkania, którym towarzyszył dźwięk fletu odbywały się wyłącznie w męskim gronie (Sukmawati 2006, 69-72), co oznacza, że zarówno muzycy jak i śpiewacy byli mężczyznami.

Saluang darek, ma tradycyjnie także inne, w pewnym stopniu ukrywane zastosowanie. Wykorzystywany bywa, przez specjalnie przygotowane do tego osoby, do rytuałów magicznych. Wykonany zgodnie zokreślonymi zasadami i używany do czarów instrument w regionie Payakumbuh nazywa się saluangsirompak. Jego konstrukcja jest taka jak saluang darek, ale procesowi jego wykonywania towarzyszy szereg rytuałów. Według wierzeń miejscowej ludności, saluangsirompak wykonany mógł być tylko z kawałka bambusa zdobytego w określony sposób, czyli znalezionego $\mathrm{w}$ wodzie, przed meczetem, zawieszonego wśrodku rosnącej kępy, złamanego samoistnie (bez udziału człowieka), lub 
ukradzionego z domostwa, w którym używany był do suszenia prania. Nie mógł być ucięty samodzielnie przez osobę, która planowała wykonanie instrumentu (Erizal 1990, 47). Odpowiedni sposób pozyskania materiału miał zapewniać większą moc magiczną powstałego $\mathrm{z}$ niego fletu. Zgodnie zwierzeniami, zakazane było również wykonanie wszystkich otworów palcowych w tym samym czasie. Każdy z nich mógł być zrobiony po jednym z następujących wydarzeń: po śmierci człowieka przez powieszenie lub uderzenie pioruna, po krwawej śmierci lub nagłej śmierci kobiety w ciąży. Jeden z otworów można też było wypalić po usłyszeniu sokoła w środku nocy. Tylko w momencie kiedy budowniczy instrumentu usłyszał o którymś z tych wydarzeń (nie powinien być natomiast ich bezpośrednim świadkiem), mógł wykonać jeden otwór palcowy. (Erizal 1990, 49). O tych zasadach wspominał także podczas rozmowy ze mną muzyk o imieniu Syahrial: „Kiedy ktoś krwawo umrze można zrobić jeden, pierwszy [otwór]. Następnie trzeba poczekać aż umrze kolejna osoba, dopiero można zrobić kolejny otwór. Ale liczą się tylko śmierci ekstremalne. Takie są wierzenia. Ale ja tego nie praktykuję" (Syahrial 2011).

Saluangsirompak był używany do opętania dziewczyny na zamówienie chłopaka, którego zaloty zostały przez nią odrzucone. Jeśli jednak odmówiła mu w sposób grzeczny, magia na nią nie działała. W procesie „czarowania” uczestniczyły najczęściej 3 osoby: pawang (szaman wypowiadający mantry i grający na gasiangtangkurak4), tukangombuhsaluangsirompak (osoba grająca na saluangsirompak), tukangsoga (osoba wchodząca w trans, wydająca okrzyki, tańcząca itp.) (Marzam 2008, 206).

Przed odprawieniem rytuału osoba zamawiająca go musi przygotować i dostarczyć szamanowi ofiarę (pambaokan) składającą się z żółtego ryżu, odpowiednio przygotowanych ziaren ryżu (barehrondang), lubianego przez duchy rodzaju kwiatów (bungopanggia-panggia), kadzidła oraz czegoś należącego do dziewczyny, którą chce opętać (włosów, paznokcia, fragmentu stroju, zdjęcia itp.). Szaman udaje się ze swymi pomocnikami i z wymienionymi wcześniej przedmiotami kolejno na siedem odpowiednich cypli i na każdym z nich odprawia rytuał, podczas którego składa dary, pali kadzidło, wypowiada mantry przy dźwiękach saluangsirompak, a tukangsogaudaje, że wpada w trans, tańczy, wspina się i krzyczy, po to, aby to samo działo się z dziewczyną ku której skierowany jest rytuał (Marzam 2008, 215-16). Współcześnie niewiele osób przyznaje się do stosowania czarnej magii, ale powszechna wiedza o niej i wiara w jej oddziaływanie sugerują, że w rzeczywistości jest inaczej. Szamanka, która zgodziła się porozmawiać ze mną na ten temat przyznała, że praktykuje i nadal ma zamówienia na wykonywanie takich rytuałów. Podkreślała jednak, że dawniej odprawiała ich znaczenie więcej (Nurida 2013). Ma to związek z oficjalnymi zakazami wykorzystywania omawianego instrumentu

${ }_{4}^{4}$ Gasiangtangkurak narzędzie dźwiękowe składające się z płytki z dwoma, centralnie umieszczonymi otworami, przez które przeciągnięty jest sznurek. Wprawiona w ruch obrotowy płytka wydaje buczący dźwięk. Patrz:Szymańska-Ilnata 2015a 
w celach zagrażających dobru społeczności oraz sprzeciwom lokalnych znawców prawa zwyczajowego lub dostojników religijnych (Syeilendra 2000, 57). Osoby trudniące się czarną magią ujawniają swoją działalność jedynie zaufanym osobom obawiając się problemów, jakie mogłyby ich spotkać, gdyby dowiedzieli się o tym ich zagorzali przeciwnicy.

Oprócz dwóch omówionych wcześniej, tradycyjnych zastosowań fletu saluang, w ciągu ostatnich kilkudziesięciu lat pojawiają się także nowe. Wpłynęły na to przede wszystkim dążenia do modernizacji muzyki tradycyjnej, dostęp do nowych technologii, zaadaptowanie instrumentów pochodzących z innych obszarów kulturowych, a także zmiany w życiu miejscowej ludności i kontakty z innymi kulturami, w których dużą rolę odgrywają także emigranci z regionu Minangkabau.

\section{Przemiany w kulturze muzycznej Minangkabau}

Pierwszą zmianą $\mathrm{w}$ zastosowaniu instrumentu było rozpoczęcie publicznych występów muzyków grających na saluang, które miały miejsce podczas lokalnych uroczystości, takich jak ustanowienie nowego przywódcy wioski czy świąt (Erizal 1990, 30). Muzycy, dotychczas grający w odosobnieniu lub przed niewielką grupą ludzi, zaczęli prezentować swoje umiejętności publicznie. Uczyli się wzajemnie od siebie i poprzez własne eksperymenty. $Z$ przeprowadzonych przeze mnie rozmów $\mathrm{z}$ aktywnymi obecnie muzykami wynika, że na Sumatrze nie funkcjonował system ścisłej zależności mistrz-uczeń. Niewielu z moich rozmówców uczyło się gry na instrumencie w dzieciństwie. Większość z nich zainteresowała się praktyką muzyczną będąc nastolatkami. Uczyli się zatem podpatrując starszych, bardziej doświadczonych muzyków oraz naśladując ich. Często nawiązywali także kontakty z takimi muzykami oraz uczyli się wspólnie z rówieśnikami - jeden od drugiego. Starsi muzycy czasem udzielali jakichś wskazówek młodszym kolegom, ale ich kontakty nie przybierały raczej formy regularnej nauki (Bahar 2013; Dt. Mangkuto Sunaro 2013; Katik Parau 2015).Można zatem uznać, że aktywne obecnie, starsze pokolenie muzyków grających na flecie to $\mathrm{w}$ większości osoby ćwiczące grę samodzielnie. Współcześnie muzycy grający na saluang darek nie zawsze są samoukami. Lekcje gry na tym instrumencie odbywają się w szkołach średnich i wyższych, na wydziale Sendratasik (Seni-Drama-Tari-Musik czyli sztuki-teatru-tańca-muzyki) na Uniwersytecie Negeri Padang oraz w Instytucie Sztuki Indonezyjskiej w PadangPanjang. Dodatkowym źródłem inspiracji oraz pomocą naukową są także nagrania dźwiękowe dostępne powszechnie na Sumatrze od lat 70. XX w.Warto w tym miejscu zaznaczyć, że pierwszych nagrań dźwiękowych na tym terenie dokonywano już w latach 30, choć nie obejmowały one wielu gatunków muzycznych. Wiadomo jednak, że już w 1931 r. Jaap Kunst nagrał na Sumatrze Zachodniej między innymi śpiew $\mathrm{z}$ towarzyszeniem fletu (Suryadi 2003, 58). 


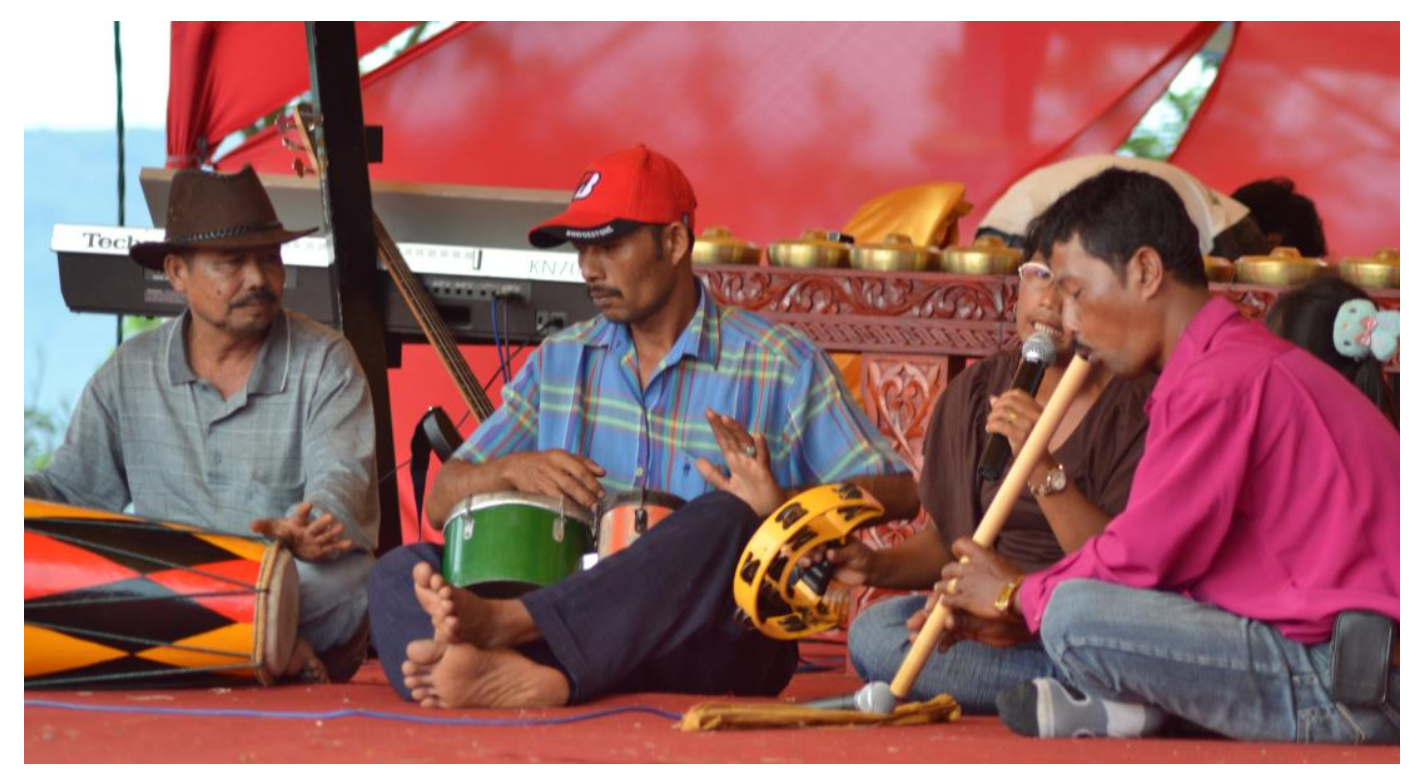

Fot. 3Muzycy prezentujący nowoczesny styl muzyczny; fot. Maria Szymańska-Ilnata, $2013 \mathrm{r}$.

Jak wspomniano wyżej, saluang darek używany jest do odprawiania rytuałów czarnej magii, ale znacznie częściej do wykonywania akompaniamentu do pieśni. Owe pieśni wykonywane są zazwyczaj w duecie zwanym saluangjodendang (flet i śpiew) składającym się $\mathrm{z}$ muzyka grającego na flecie oraz śpiewaka. Występują oni najczęściej wieczorami podczas swego rodzaju koncertów zwanych bagurau lub balambokmalam. Na początku pieśni często pojawiają się słowa „oisaluangtolongsampaikan” (O! saluangu proszę przekaż...), po których opisywane są uczucia, które muzyka ma wywołać u publiczności. Są one wzbudzane przez opowieści przedstawiane przez śpiewaka oraz używany przez niego symboliczny język (Syeilendra 2000, 54-55). Miejscem takich występów były początkowo przenośne jadłodajnie zwane kaki lima, a następnie większe, stacjonarne restauracje. Gromadzili się w nich muzycy i osoby, które chciały odpocząć czy poplotkować przy dźwiękach muzyki. Jeszcze do lat 6o. XX w. były to jednak rozrywki zarezerwowane wyłącznie dla mężczyzn. Dopiero na przełomie lat 60. i 70. następować zaczęły przemiany obyczajowe i kobiety pojawily się w świecie teatru i muzyki (Sukmawati 2006, 118-24). W pierwszej kolejności dopuszczone zostały do odgrywania ról kobiecych $\mathrm{w}$ tradycyjnym teatrze randai 5 . Dotychczas w role te wcielali się młodzi mężczý́ni o łagodnych rysach twarzy i delikatnej budowie ciała. W drugiej kolejności kobiety wywalczyły możliwość występowania w roli śpiewaczek $\mathrm{w}$ duetach saluangjodendang, a następnie $\mathrm{w}$ zespołach muzycznych towarzyszących teatrowi randai oraz innych formach tradycyjnej muzyki.

5 Teatr tradycyjny wywodzący się od sztuki walki pencaksilat trenowanej przez młodych mężczyzn. Patrz: Szymańska-Ilnata 2015b 
Obecnie kobiece głosy zdecydowanie dominują na scenach, zarówno w pieśniach tradycyjnych, jak i bardziej nowoczesnych.

Na kolejne przemiany w muzyce duży wpływ miały powstające od połowy $\mathrm{XX}$ w. nowe gatunki muzyczne, a przede wszystkim dangdut. Muzycznie był on połączeniem elementów zaczerpniętych $\mathrm{z}$ muzyki z hinduskich filmów, muzyki do malajskiego tańca joged, a później także wzorców motywów basowych pochodzących z muzyki reggae (Barendregt i van Zanten 2002, 77). Szczególne znaczenie miał tu rytm, który zaczął być przenoszony na grunt muzyki tradycyjnej. Dotychczas istniejące zespoły złożone z muzyka i śpiewaczki poszerzano o muzyka lub dwóch grających na bębnach. Wykonywali oni charakterystyczne dla muzyki dangdut rytmy. Występy zespołów saluangjodendang radykalnie zmieniły swój charakter. Tradycyjnie wykonywane melodie zwane ratok miały raczej nostalgiczny charakter. Opowiadały o smutnych wydarzeniach, nieszczęśliwej miłości oraz tęsknocie za rodzinnym domem odczuwanej przez osoby przebywające na emigracji. Nowa muzyka była natomiast radosna i taneczna, a pisane do niej teksty zawierały najczęściej miłosne wyznanie.

Wraz z szerszym dostępem do mass mediów oraz wzorców z zewnątrz następować zaczęły kolejne zmiany społeczne. Jedne z najbardziej widocznych dotyczyły strojów. Piosenkarki wykonujące muzykę dangdut nosiły coraz bardziej wyzywające stroje, co naśladować zaczęły także niektóre śpiewaczki saluangjodendang. W związku z tym ich występy były krytykowane przez wyznawców bardziej ortodoksyjnych poglądów. Współcześnie strój śpiewaczek zależy przede wszystkim od miejsca i okoliczności, w jakich występują. Zdecydowanie bardziej „odważne” stroje noszone są przez kobiety śpiewające w przydrożnych barach czy restauracjach, natomiast stroje zgodne $\mathrm{z}$ muzułmańskimi nakazami dominują $\mathrm{w}$ bardziej tradycyjnym środowisku, podczas występów na weselach czy festiwalach, a przede wszystkim zakładane są przez bardziej religijne śpiewaczki. Dobór stroju jest osobistym wyborem śpiewaczki, które zdają sobie sprawę z tego, że wśród lokalnej społeczności zawsze znajdą osoby o poglądach zbliżonych do własnych, a tym samym publiczność chętną do wysłuchania ich koncertu. 
Fot. 4 Muzyk i cztery śpiewaczki podczas występóww lokalnej restauracji; fot. Maria Szymańska-Ilnata, 2015 r.

Bagurau czyli wieczorne spotkania przy muzyce w kawiarniach i restauracjach odbywają się na Sumatrze Zachodniej często. Występujące w takich miejscach zespoły nie mają stałego składu. Organizator spotkania, najczęściej przedstawiciel restauracji, zaprasza na określony dzień jednego muzyka grającego na flecie, co najmniej dwie śpiewaczki oraz muzyka grającego na keyboardzie. Publiczność stanowią zazwyczaj młodzi mężczyźni z okolicy. Za drobną opłatą mogą oni zamówić dowolną piosenkę, ze znanego powszechnie repertuaru. Należą do niego zarówno tradycyjne pieśni zwane ratok, jak i nowoczesne, w stylu dangdut czy pop-Minang. Spotkania takie trwać mogą niemal do rana. Bardzo często śpiewaczek jest kilka więc na zmianę wykonują piosenki. Powszechną praktyką jest także dzielenie się zwrotkami poszczególnych utworów oraz tworzenie własnych tekstów nawiązujących do bieżących wydarzeń.

Inną okazją do występów są festiwale muzyczne różnego szczebla oraz lokalne uroczystości, na których zespoły prezentują różnorodny repertuar. Część festiwali poświęconych jest wyłącznie tradycyjnej muzyce, inne z kolei koncentrują się na współczesnych kompozycjach. Organizowane są one najczęściej przez urzędy do spraw kultury i turystyki, których zadaniem jest między innymi wspieranie działalności lokalnych zespołów.

Niewątpliwie bardzo istotne znaczenie dla przemian obserwowanych w lokalnej kulturze miało pojawienie się oraz rozwój mass mediów i nowoczesnych technologii rejestracji dźwięku. Dziś chyba już nikt nie wyobraża sobie pejzażu dźwiękowego sumatrzańskich bazarów i ulic bez docierającej z różnych źródeł muzyki. Dominują w nim piosenki w stylu pop-Minang, wywodzącym się $\mathrm{z}$ fuzji wspomnianej wcześniej muzyki dangdut $\mathrm{z}$ lokalnymi tradycjami muzycznymi. Jest to kolejny gatunek muzyczny, w którym wykorzystywane są instrumenty tradycyjne. Jednym z ważniejszych jest saluang. Jak wspomniano wyżej, do muzyki współczesnej konstruowane są specjalne flety, na których nie wykonuje się muzyki tradycyjnej. Najważniejsza różnica pomiędzy nimi to strój. Flety 
wykorzystywane do muzyki rozrywkowej/współczesnej mają mniejszą średnicę oraz wyższe brzmienie.

Zasygnalizowane powyżej przemiany w muzyce Minangkabau są wynikiem zmieniających się gustów publiczności, oddziaływania obcych wzorców kulturowych - przede wszystkich zachodniej kultury masowej, ale także działań politycznych. Jednym z dążeń władz lokalnych i państwowych jest unowocześnianie tradycyjnej muzyki, aby była atrakcyjna dla młodszej, często żyjącej w miastach publiczności. Znaczący wpływ na muzykę tworzoną w regionie Minangkabau ma również diaspora. Wydaje się, że w dużej mierze to dla ludzi mieszkających na emigracji powstawały kasety, a współcześnie tworzone są płyty VCD zawierające pieśni mówiące o tęsknocie za domem, odnoszące się do tradycyjnych powiedzeń i opowieści. Dla muzyki pop-Minang wydawanej na bardzo popularnych i tanich płytach VCD charakterystyczne są takie elementy jak zastosowanie emblematycznych instrumentów (saluang, talempong ${ }^{6}$ ), tradycyjne stroje noszone przez muzyków i śpiewaków, charakterystyczne elementy krajobrazu (tradycyjne domy, najważniejsze naturalne atrakcje turystyczne - wodospady, jeziora, kaniony). Zadaniem pop-Minang jest zaspokoić muzyczne potrzeby zarówno ludzi mieszkających w rejonie Minangkabau, jak i na emigracji. Jest tym samym elementem tworzącym poczucie więzi i wspólnoty oraz pomagających określić własną tożsamość etniczną (Barendregt i van Zanten 2002, 69). Młodzi ludzie z rejonu Minangkabau słuchając tej muzyki czują związek $\mathrm{z}$ tradycją dzięki zastosowanym instrumentom, tematyce i elementom wizualnym. $Z$ drugiej strony widzą jej nowoczesność, która objawia przede wszystkim w sferze rytmicznej oraz obecności instrumentów elektrycznych, takich jak keyboard czy gitary.Osoby urodzone i wychowane w dużych miastach, w różnych zakątkach Indonezji, mające świadomość pochodzenia z grupy etnicznej Minangkabau często potrzebują elementów tradycyjnej kultury dla konstruowania własnej tożsamości. Tradycyjne formy muzyczne, z racji ich odmienności od muzyki, której takie osoby słuchają na co dzień, mogą sprawiać trudności percepcyjne. Pop-Minang jest znaczenie latwiejszy w odbiorze, ponieważ zastosowane są skale muzyczne obecne w muzyce zachodniej i popularnej muzyce indonezyjskiej. Zawiera jednak idiom Minangkabau, który nawiązuje do korzeni i pozwala eksponować indywidualność słuchacza.

Na przykładzie tego krótkiego rysu rozwoju gatunków muzycznych oraz sposobu zastosowania saluang darek widać wyraźnie jak mocno zmieniła się kultura muzyczna Sumatry Zachodniej w ciągu ostatniego stulecia. Przyczyny tych zmian są liczne i różnorodne, poczynając od kontaktów z przedstawicielami innych kultur, rozwoju technologicznego, po przemiany globalizacyjne. Wpływ na nie mają nie tylko zmieniające się gusta jednostek, lecz także polityka kulturowa regionu i państwa, rozwój

${ }^{6}$ Jeden z najważniejszych instrumentów Minangkabau, składający się tradycyjnie z 5-6 niewielkich gongów, które dzielone są pomiędzy 3 muzyków. Podczas gry muzycy uderzają drewnianymi pałkami w trzymane w dłoniach gongi. 
turystyki, kontaktów handlowych i naukowych oraz wiele innych czynników. Śledzenie dalszego rozwoju zarówno nurtu tradycyjnego, jak i nowoczesnego będzie z pewnością fascynujące dla muzykologów i badaczy kultury przez kolejne lata.

\section{Bibliografia}

Barendregt, Bart, i Wim van Zanten. 2002. „Popular Music in Indonesia since 1998, in Particular Fusion, Indie and Islamic Music on Video Compact Discs and the Internet”. Yearbook for Traditional Music 34: 67-113. doi:10.2307/3649190.

Erizal. 1990. Instrumen tiup karawitan Minangkabau. Padang Panjang: ASKI.

Fraser, Jennifer A. 2015. Gongs and Pop Songs: Sounding Minangkabau in Indonesia. Athens: Ohio University Press.

Marzam. 2008. „Basirompak: The Revenge Manifestation of Minangkabau Community of Taeh Baruah, Payakumbuh, West Sumatera”, Journal of Southeast Asian Studies, 13 (1).

Sukmawati, Noni. 2006. Ratapan perempuan Minangkabau dalam pertunjukan bagurau: gambaran perubahan sosial Minangkabau. Padang, Indonesia: Andalas University Press.

Suryadi. 2003. „Minangkabau Commercial Cassettes and the Cultural Impact of the Recording Industry in West Sumatra”. Asian Music 34 (2): 51-89.

Syeilendra. 2000. Musik Tradisi. Padang: Universitas Negeri Padang.

Szymańska-Ilnata, Maria. 2015a. „Magiczne właściwości muzyki na przykładzie rytuału basirompak z Zachodniej Sumatry”. Codzienność rytuału. Magia w życiu społeczeństw Azji Potudniowo-Wschodniej, zredagowane przez Adrian Mianecki. Paralele: Folklor - Literatura Kultura. Toruń: Wydawnictwo Naukowe UMK.

- - . 2015b. „Synteza sztuk w teatrze randai z Sumatry Zachodniej”. Ogród sztuk Indonezji/Taman Seni Indonesia, zredagowane przez Małgorzata Jarmułowicz. Verbinum, Górna Grupa.

\section{Wywiady}

Bahar. 2013. Muzyk grający na saluang.

Bolon. 2015. Muzyk grający na saluang.

Dt. MangkutoSunaro. 2013. Muzyk grający na saluang.

KatikParau. 2015. Muzyk grający na saluang.

Nurida. 2013. szamanka grająca na gasiang.

Syahrial. 2011. Muzyk grający na saluang. 